\title{
THYROID FUNCTION ASSAY WITH RADIOIODINE. II. ROUTINE CALCULATION OF THYROIDAL AND RENAL RATE FACTORS ${ }^{1}$
}

\author{
BY T. H. ODDIE, ${ }^{2}$ I. MESCHAN, AND J. WORTHAM \\ (From the Department of Radiology and Department of Medicine, \\ University of Arkansas, Little Rock, Ark.)
}

(Submitted for publication May 7, 1954; accepted August 30, 1954)

In the preceding paper (1) mathematical equations and numerical data were presented describing the early movement of a test dose of radioiodine in the human body. The information given can be used directly to calculate thyroidal uptake and renal excretion rate factors (or clearance rates) from observed values of the fractions of the net dose in the neck, $N$, and urine $E$, without the need for any blood samples, but the process is rather too tedious for routine use. However, the procedure can be greatly simplified by making suitable charts relating $\mathrm{N}$ and $\mathrm{E}$ to the thyroidal, $\mathrm{k}_{1}$, and renal, $\mathrm{k}_{2}$, rate factors for selected fixed times $t$ after injecting the test dose. Fixed time schedules are necessary because otherwise a large number of charts is required. For convenience the pertinent equations from the preceding paper (1) are repeated below:

$$
\begin{gathered}
\mathrm{k}=\mathrm{k}_{1}+\mathrm{k}_{2} \\
\mathrm{k}_{1} / \mathrm{k}=\frac{\mathrm{N}-\mathrm{N}_{0} \mathrm{~V}_{\mathrm{n}} / \mathrm{N}+\mathrm{EN} \mathrm{N}_{\mathrm{n}} / \mathrm{S}}{\mathrm{N}-\mathrm{N}_{0} \mathrm{~V}_{\mathrm{n}} / \mathrm{N}+\mathrm{E}} \\
\mathrm{k} \phi \mathrm{t}=\ln \frac{1-\mathrm{N}_{0} V_{\mathrm{n}} / \mathrm{S}}{1-\mathrm{N}-\mathrm{E}}
\end{gathered}
$$

All the symbols used are as defined in the preceding paper (1), namely:

$E=$ The fraction of the original dose excreted by the kidneys up to time $t$ minutes after injection.

$\mathbf{k}$ min. $^{-1}=$ The average combined (thyroid plus kidneys) fractional rate of removal of radio-iodide from the iodide space during the time interval $\mathrm{t}=0$ to 30 minutes: that is, an average fraction $\mathrm{k}$ of the circulating iodide pool is removed each minute.

$k_{1} \min ^{-1}=$ The average fractional rate of uptake by the thyroid from $t=0$ to 30 minutes.

$k_{2} \min ^{-1}=$ The average fractional rate of renal excretion from $\mathrm{t}=0$ to 30 minutes.

$\mathrm{N}=$ The fraction of the original dose observed in the neck by external counting at time $t$, including both thyroid and extra-thyroid tissues.

${ }^{1}$ University of Arkansas Research Series No. 1007. Assisted by Grants numbers C-1866 and H-1702, from the National Institute of Health, Division of Research Grants. 2 Fulbright Fellow.
$N_{0}=$ The initial value of $N$ at time $t=0$ assuming instantaneous mixing of the dose with the circulating plasma.

$\mathrm{t}$ min. $=$ The time from injection of the test dose.

$\mathrm{V} \mathrm{ml}$. = The volume of the total effective iodide space at time $\mathrm{t}$.

$\mathrm{V}_{\mathrm{n}} \mathrm{N}_{0} \mathrm{ml}$. = The apparent volume of iodide space, at time $t$, that is "observed" in the extra-thyroid neck tissues by the external counter.

$\phi=$ The average value of $1 / \mathrm{V}$ up to time $\mathrm{t}$ expressed as a fraction of the average up to $t=30$ minutes.

The above three equations are all that are needed for the development of simple routine methods and charts, as will be shown in the following sections.

\section{EXTRA-THYROIDAL RADIOIODINE CONTENT OF NECK TISSUES OBSERVED BY EXTERNAL COUNTER}

The term $\mathrm{N}_{0} \mathrm{~V}_{\mathrm{n}} / \mathrm{V}$ in equations (2) and (3) is derived from the fraction of the net dose observed in the extra-thyroidal neck tissues at time $t$, which has been shown (1) to be given by $\frac{N_{0} V_{n} e^{-k \phi t}}{V}$. It has also been shown that $V_{n} / V$ varies with time, but average smoothed values of this ratio have been tabulated in the form $\frac{V_{n} / V}{\left(V_{n} / V\right)_{2}}$-where the denominator represents the value of $V_{n} / V$ at exactly two minutes after injection.

If then, $\mathrm{N}_{0} \mathrm{~V}_{\mathrm{n}} / \mathrm{V}$ (at any particular time $\mathrm{t}$ ) can be treated as a constant for all patients, equations (1), (2) and (3) can be represented on only one pair of charts connecting $\mathrm{k}_{1}$ and $\mathrm{k}_{2}$ with $\mathrm{N}$ and $\mathrm{E}$ for each selected time $\mathrm{t}$; but if $\mathrm{N}_{0} \mathrm{~V}_{\mathrm{n}} / \mathrm{V}$ varies too widely from patient to patient, a large number of pairs of charts must be constructed to cover the range of variation of this factor. Moreover, there is the additional advantage that if $\mathrm{N}_{0} \mathrm{~V}_{\mathrm{n}} / \mathrm{V}$ is known with sufficient accuracy for all patients, there will usually be no need to make an initial in vivo count over the neck immediately after injection.

Obviously variations from patient to patient 


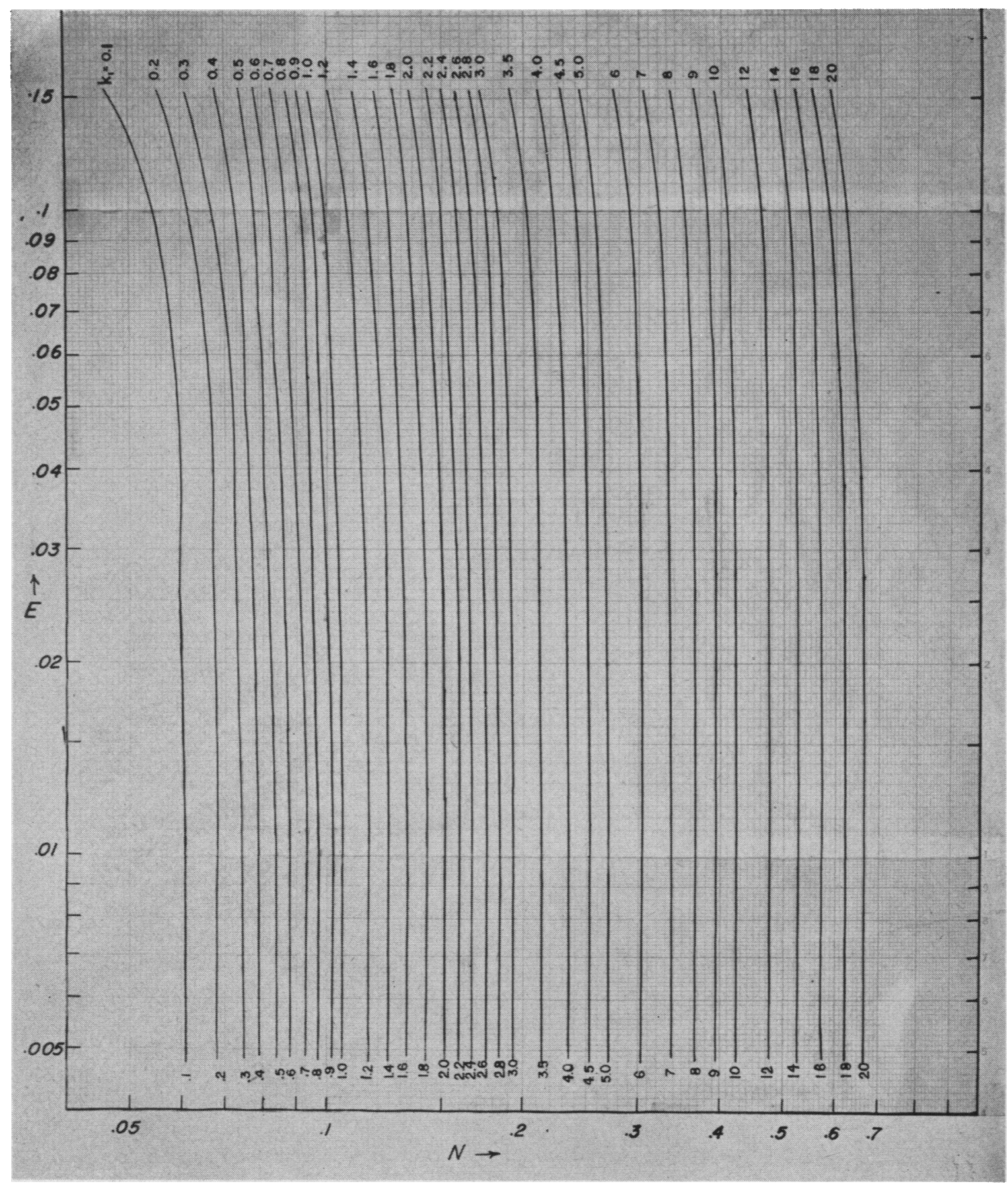

Fig. 1. Chart for Thyroidal Rate $k_{1}$ Measured at One Hour $(t=60)$

become less troublesome when the extra-thyroidal tissue contribution $\mathrm{N}_{0} \mathrm{~V}_{n} / \mathrm{V}$ is kept small by careful collimation of the external counter; to provide some data on this point we have measured the value of $\mathrm{N}_{0}\left(\mathrm{~V}_{\mathrm{n}} / \mathrm{V}\right)_{2}$ - that is the extra-thyroidal neck tissue fraction two minutes after injectionin the same athyroid patient with four different counting arrangements with the results presented in Table I.

The benefit derived from using a long collimator is apparent from the reduced value of the contribution of the neck tissues. In addition we have made observations on two series of different patients with long and short collimators, finding 
mean values with standard deviations of the individual values set out in Table II.

Here again the long collimator gives more concordant results, and by using it for routine uptake studies $\mathrm{N}_{0}\left(\mathrm{~V}_{\mathrm{n}} / \mathrm{V}\right)_{2}$ can be taken as 0.071 , with a maximum expected variation of about \pm .027 , for all cases except doubtful ones undergoing repeated tests; such cases occur sometimes when the numerical results of a first test lie close to the diagnostic borderline values separating euthyroid and hyperthyroid groups.
For the latter exceptional cases, or for collimators of different shape, it is necessary to deduce the individual values of $N_{0} V_{n} / V$ from the initial and final total counts over the neck. This can be done by approximating equation (11) of the preceding paper for times $t$ and two minutes, finally obtaining the approximate relation

$$
\begin{aligned}
\mathrm{N}_{0} \mathrm{~V}_{\mathrm{n}} \mathrm{V}=\left[\phi \mathrm{t} \mathrm{N}_{2}-4.3 \mathrm{~N}\right] / \\
\\
\left.\qquad \frac{\phi \mathrm{t}\left(\mathrm{V}_{\mathrm{n}} / \mathrm{V}\right)_{2}}{\mathrm{~V}_{\mathrm{n}} / \mathrm{V}}-4.3\right]
\end{aligned}
$$

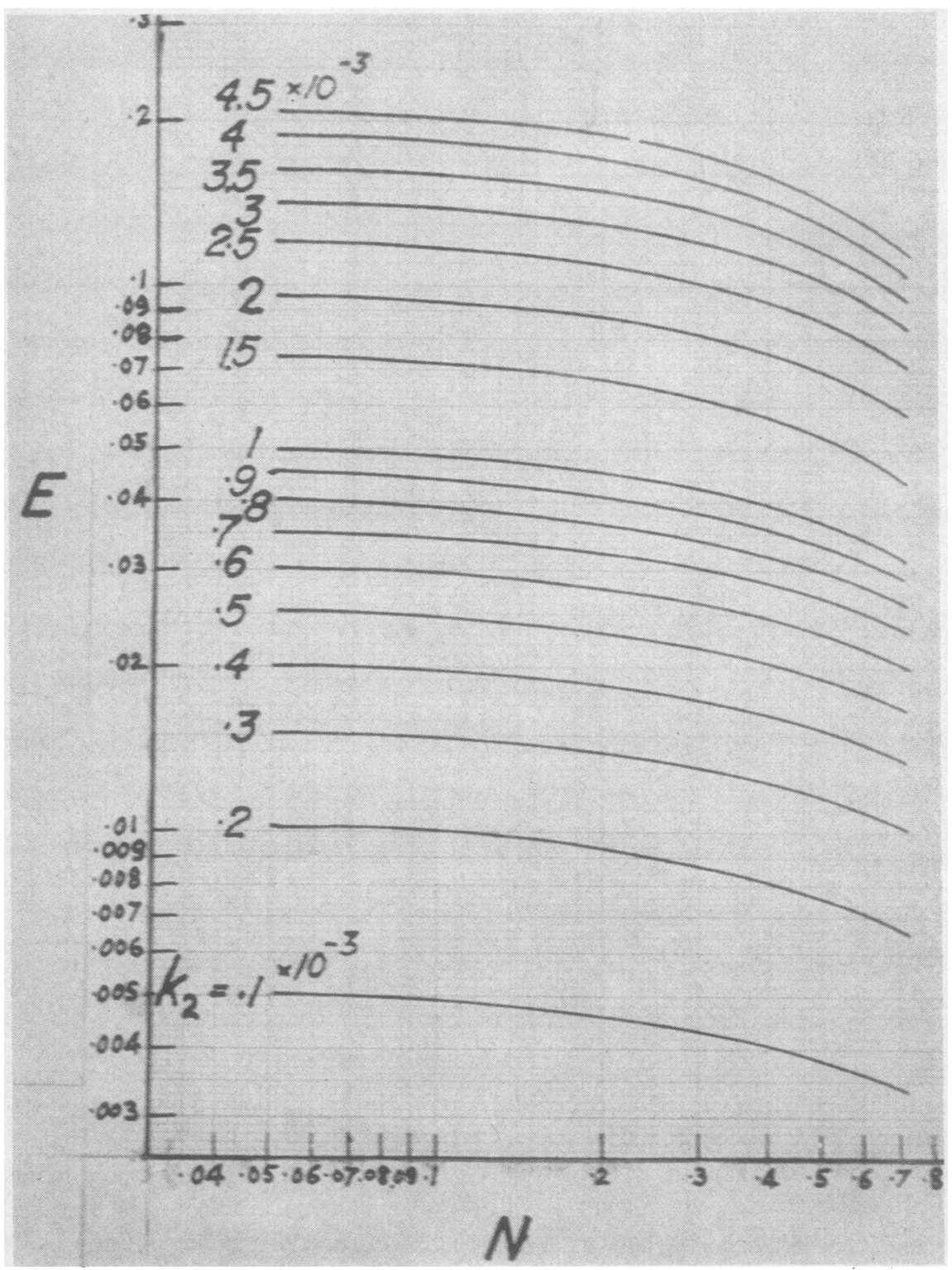

Fig. 2. Chart for Renal Rate $\mathrm{k}_{2}$ Meastred at ONe Hovr $(t=60$ minutes) 


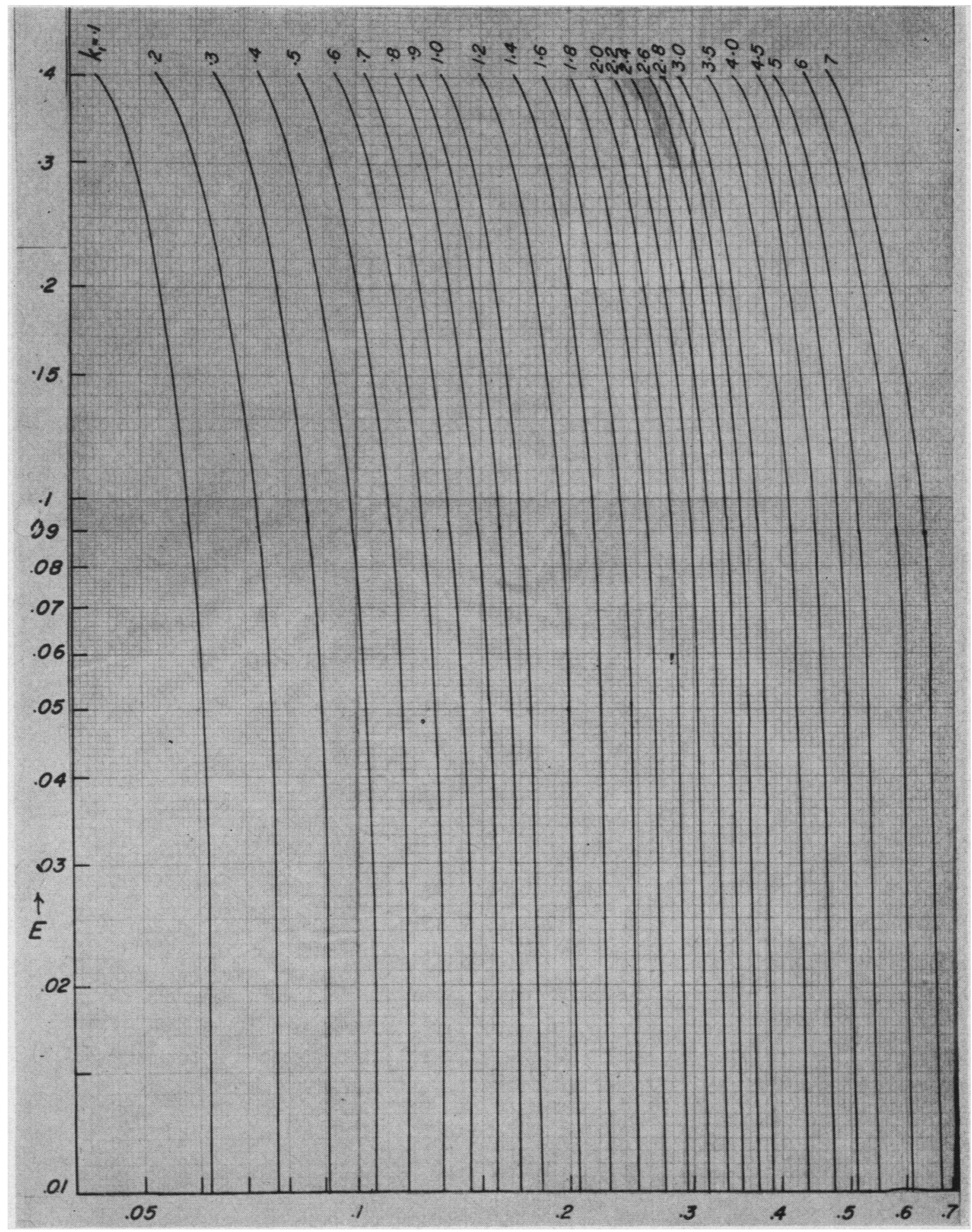

Fig. 3. Chart for Thyroidal Rate $k_{1}$ Measured at Four Hours $(i=240)$ 


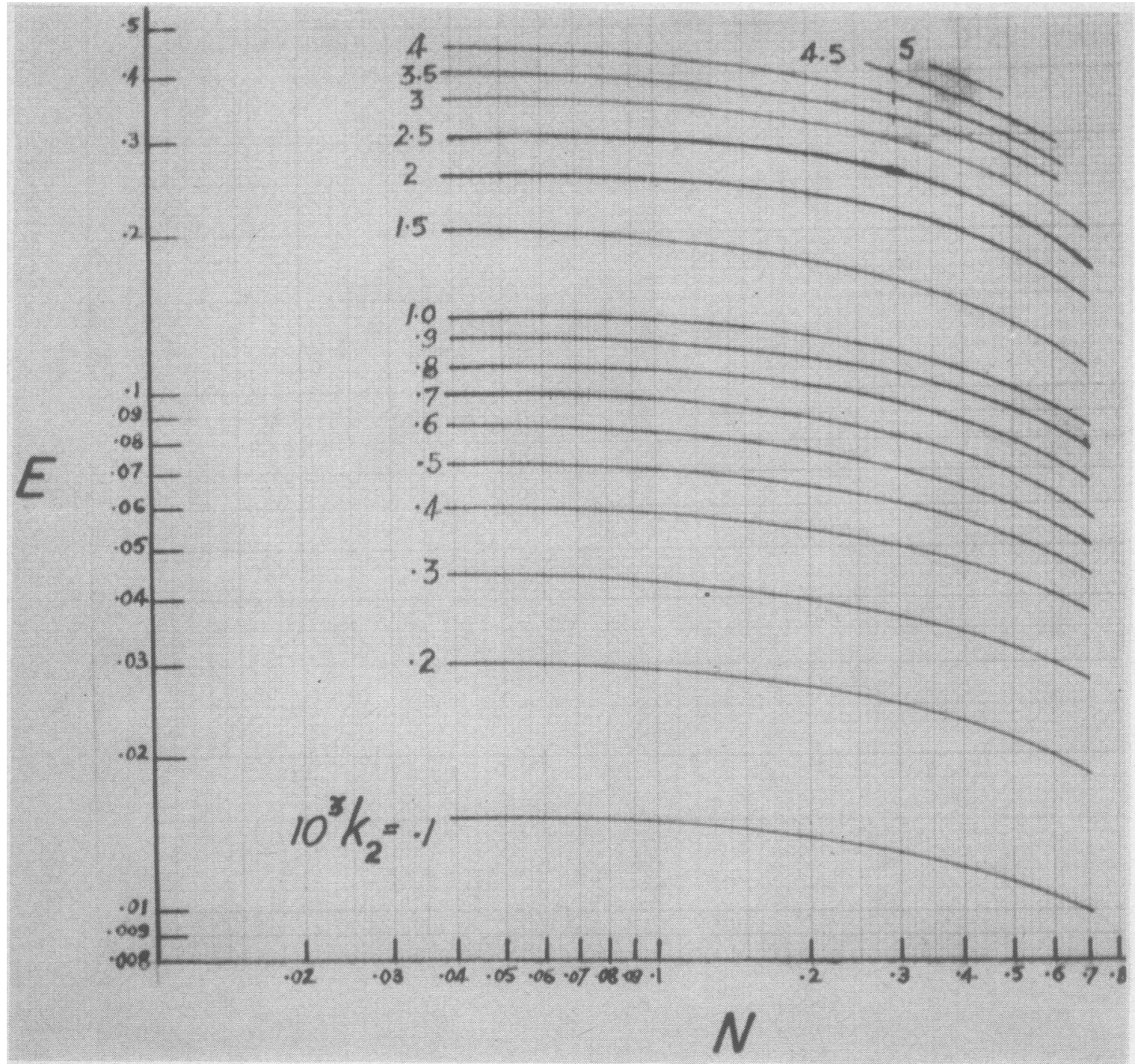

Fig. 4. Chart for Renal Rate $k_{2}$ Measured at Folr Holrs $(t=240)$

TABLE I

\begin{tabular}{|c|c|c|}
\hline Counting arrangement & $\begin{array}{l}\text { Estimated area } \\
\text { of neck and } \\
\text { torso observed, } \\
\text { including } \\
\text { penumbral } \\
\text { region }\end{array}$ & $\begin{array}{c}\text { Observed } \\
\mathrm{N}_{0}\left(\mathrm{~V}_{\mathrm{n}} / \mathrm{V}\right)_{2}\end{array}$ \\
\hline $\begin{array}{l}\text { Cylindrical Geiger counter in } \\
\text { transverse position } 15 \mathrm{~cm} \text {. } \\
\text { from skin; open type lead } \\
\text { shield similar to arrangement } \\
\text { of Werner, Quimby, and } \\
\text { Schmidt (2) }\end{array}$ & $550 \mathrm{~cm}^{2}$ & .126 \\
\hline $\begin{array}{l}\text { End window Geiger counter, } \\
15 \mathrm{~cm} \text {. from skin, in cylin- } \\
\text { drical lead shield of open } \\
\text { type. }\end{array}$ & $250 \mathrm{~cm}^{2}$ & .106 \\
\hline $\begin{array}{l}\text { Scintillation counter, } 47 \mathrm{~cm} \text {. } \\
\text { from skin, short collimator } \\
\text { as described earlier (1) }\end{array}$ & $1000 \mathrm{~cm}^{2}$ & .151 \\
\hline $\begin{array}{l}\text { Scintillation counter, } 47 \mathrm{~cm} \text {. } \\
\text { from skin, long collimator as } \\
\text { described earlier (1) }\end{array}$ & $200 \mathrm{~cm} .^{2}$ & .073 \\
\hline
\end{tabular}

or, if the initial count is taken over the period 2 to 10 minutes

$$
\begin{aligned}
\mathrm{N}_{0} \mathrm{~V}_{\mathrm{n}} / \mathrm{V}=\left[\phi \mathrm{tN}_{2,10}-8.9 \mathrm{~N}\right] / \\
\\
{\left[\frac{.95 \phi \mathrm{t}\left(\mathrm{V}_{\mathrm{n}} / \mathrm{V}\right)_{2}}{\mathrm{~V}_{\mathrm{n}} / \mathrm{V}}-8.9\right] }
\end{aligned}
$$

Thus, for example, if $t=60$ minutes is the time selected for the second count, the tabu-

\begin{tabular}{|c|c|c|c|c|}
\hline \multirow{2}{*}{$\begin{array}{l}\text { Colli- } \\
\text { mator }\end{array}$} & \multirow{2}{*}{$\begin{array}{c}\text { Number } \\
\text { of } \\
\text { cases }\end{array}$} & \multicolumn{2}{|c|}{$\mathrm{N}_{0}\left(\mathrm{~V}_{\mathrm{n}} / \mathrm{V}\right)_{2}$} & \multirow{2}{*}{$\begin{array}{c}\text { Standard } \\
\text { deviation } \\
\text { of indi- } \\
\text { vidual } \\
\text { readings }\end{array}$} \\
\hline & & Mean & Range & \\
\hline Short & 17 & .146 & $.074-.272$ & .047 \\
\hline Long & 24 & .071 & $.046-.100$ & .013 \\
\hline
\end{tabular}

TABLE II 
lated values required are found in Table III of the preceding paper as $\phi \mathrm{t}=\mathbf{5 0 . 8}$ minutes and $\frac{\mathrm{V}_{\mathrm{n}} / \mathrm{V}}{\left(\mathrm{V}_{\mathrm{n}} / \mathrm{V}\right)_{2}}=0.84$ so equation (5) reduces to

$$
\mathrm{N}_{0} \mathrm{~V}_{\mathrm{n}} / \mathrm{V}=1.05 \mathrm{~N}_{2,10}-0.184 \mathrm{~N}
$$

Similar computations for other times lead to the coefficients listed in Table III.

In the routine case where $\mathrm{N}_{0}\left(\mathrm{~V}_{\mathrm{n}} / \mathrm{V}\right)_{2}=0.071$ the derived figures for $N_{0} V_{n} / V$ are those in the fourth column of 'Table III.

\section{CHARTS,FOR ROUTINE TESTS}

Assuming that routine tests can be timed so that the middle of the period of the uptake ob- servations is at a preselected time, charts are readily constructed to give $k_{1}$ and $k_{2}$ directly from the observed fractions $N$ and E. Such charts for our long collimator have been derived

TABLE III

Data for finding $N_{0} V_{n} / V$

\begin{tabular}{|c|c|c|c|}
\hline \multicolumn{2}{|c|}{ Time $t$ minutes } & \multirow[b]{2}{*}{$\begin{array}{l}\text { Formula for finding } \\
\text { from two neck counts } \\
\text { NoV } n=V\end{array}$} & \multirow{2}{*}{$\begin{array}{c}\text { Mean } \\
\text { MoVn } / \mathrm{V} \\
\text { with lon } \\
\text { colli- } \\
\text { mator }\end{array}$} \\
\hline $\begin{array}{l}\text { First } \\
\text { obser- } \\
\text { vation }\end{array}$ & $\begin{array}{l}\text { Second } \\
\text { obser- } \\
\text { vation }\end{array}$ & & \\
\hline $\begin{array}{l}2 \\
2-10 \text { (mean) } \\
2-10 \\
2-10 \\
2-10 \\
2-10\end{array}$ & $\begin{array}{r}30 \\
30 \\
60 \\
120 \\
240 \\
1,440\end{array}$ & $\begin{array}{l}1.01 \mathrm{~N}_{2}-0.144 \mathrm{~N} \\
1.28 \mathrm{~N}_{2,10}-0.38 \mathrm{~N} \\
1.05 \mathrm{~N}_{2,10}-0.184 \mathrm{~N} \\
0.91 \mathrm{~N}_{2,10}-0.093 \mathrm{~N} \\
0.80 \mathrm{~N}_{2,10}-0.048 \mathrm{~N} \\
0.56 \mathrm{~N}_{2,10}-0.009 \mathrm{~N}\end{array}$ & $\begin{array}{l}.062 \\
.062 \\
.060 \\
.056 \\
.051 \\
.037\end{array}$ \\
\hline
\end{tabular}

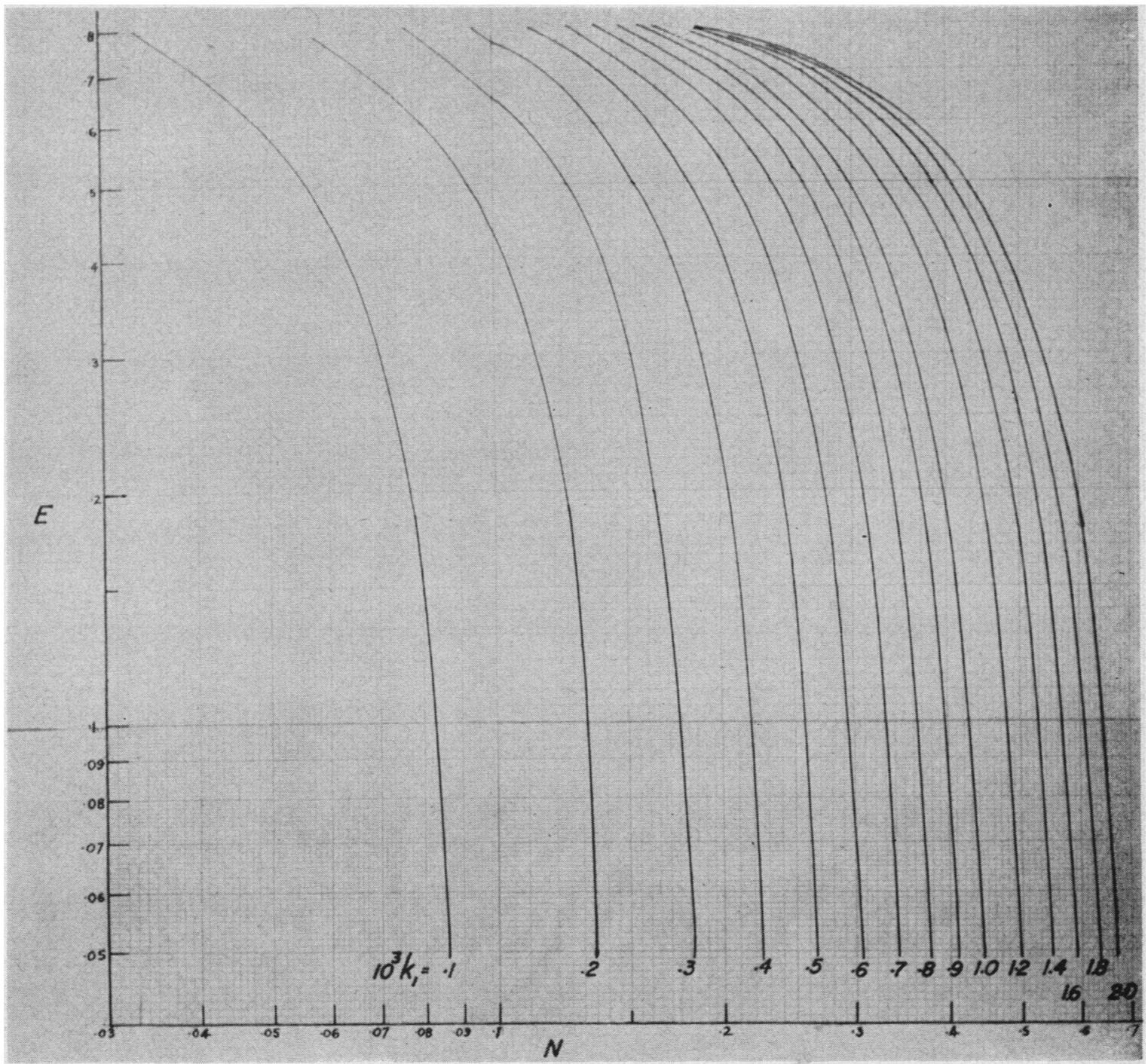

Fig. 5. Chart for Thyroidal Rate $\mathrm{k}_{1}$ Measured at 24 Hours $(t=1,440)$ 


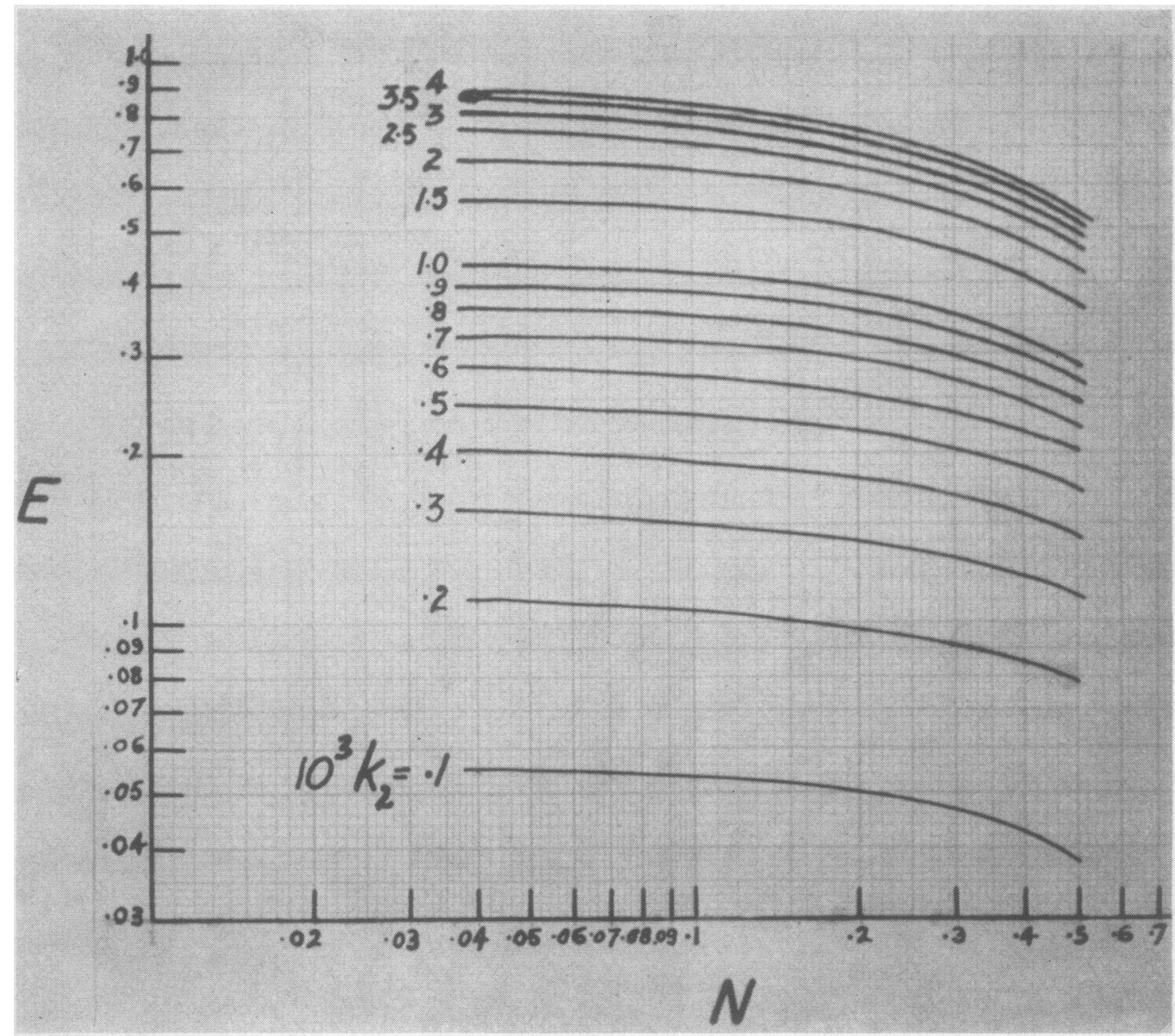

Fig. 6. Chart for Rexal Rate $k_{2}$ Meastred at 24 Hotrs $(t=1,440)$

TABLE IV

Corrections for urine collection time*

\begin{tabular}{|c|c|c|c|c|c|}
\hline$\underset{\mathrm{t}^{\dagger}}{\text { Required }}$ & $\begin{array}{l}\text { Actual } \\
\text { collection } \\
\text { timet }\end{array}$ & $\begin{array}{l}\text { Correction } \\
\text { factor for } \\
\text { observed E }\end{array}$ & $\underset{\mathrm{t}^{\dagger}}{\text { Required }}$ & $\begin{array}{c}\text { Actual } \\
\text { collection } \\
\text { timet }\end{array}$ & $\begin{array}{l}\text { Correction } \\
\text { factor for } \\
\text { observed E }\end{array}$ \\
\hline $\begin{array}{c}60 \\
(1 \text { hour })\end{array}$ & $\begin{array}{l}55 \\
60 \\
65 \\
70 \\
75 \\
80\end{array}$ & $\begin{array}{l}1.15 \\
1.07 \\
1.00 \\
0.94 \\
0.89 \\
0.84\end{array}$ & $\begin{array}{l}240 \\
(4 \text { hours })\end{array}$ & $\begin{array}{l}230 \\
235 \\
240 \\
245 \\
250 \\
255 \\
260\end{array}$ & $\begin{array}{l}1.06 \\
1.04 \\
1.02 \\
1.00 \\
0.98 \\
0.96 \\
0.95\end{array}$ \\
\hline $\begin{array}{c}120 \\
(2 \text { hours })\end{array}$ & $\begin{array}{l}110 \\
115 \\
120 \\
125 \\
130 \\
135 \\
140\end{array}$ & $\begin{array}{l}1.12 \\
1.08 \\
1.04 \\
1.00 \\
0.97 \\
0.94 \\
0.92\end{array}$ & $\begin{array}{c}1,440 \\
(24 \text { hours) }\end{array}$ & $\begin{array}{l}1,400 \\
1,415 \\
1,430 \\
1,445 \\
1,460 \\
1,475 \\
1,490\end{array}$ & $\begin{array}{l}1.03 \\
1.02 \\
1.01 \\
1.00 \\
0.99 \\
0.98 \\
0.97\end{array}$ \\
\hline
\end{tabular}

* Note that 5 minutes' lag is allowed in urine accumulation, so that urine collected at, for example, 65 minutes, is assumed to be that excreted up to $\mathrm{t}=60$.

$t$ All times in minutes from injection. 
TABLE V

Solution of equation (3) for $k$ at preselected times

\begin{tabular}{|c|c|c|c|c|c|}
\hline \multirow[b]{2}{*}{$\frac{1-N_{0} V_{n} / V}{1-N-E}$} & \multicolumn{5}{|c|}{$10^{2} \mathrm{k} \min ^{-1}$} \\
\hline & $\begin{array}{l}1 \text { hour } \\
t=30\end{array}$ & 1 hour & $\begin{array}{l}2 \text { hours } \\
120\end{array}$ & $\begin{array}{l}4 \text { hours } \\
240\end{array}$ & $\begin{array}{c}24 \text { hours } \\
1,440\end{array}$ \\
\hline $\begin{array}{l}1.00 \\
1.05 \\
1.10 \\
1.15 \\
1.20 \\
1.25 \\
1.30 \\
1.35 \\
1.40 \\
1.45 \\
1.50 \\
1.55 \\
1.60 \\
1.65 \\
1.70 \\
1.75 \\
1.80 \\
1.85 \\
1.90 \\
1.95 \\
2.00 \\
2.1 \\
2.2 \\
2.3 \\
2.4 \\
2.5 \\
2.6 \\
2.7 \\
2.8 \\
2.9 \\
3.0 \\
3.1 \\
3.2 \\
3.3 \\
3.4 \\
3.5 \\
3.6 \\
3.7 \\
3.8 \\
3.9 \\
4.0 \\
4.2 \\
4.4 \\
4.6 \\
4.8 \\
5.0 \\
5.5 \\
6.0 \\
6.5 \\
7.0 \\
8.0 \\
9.0 \\
10.0 \\
12 \\
14 \\
16 \\
18 \\
20\end{array}$ & 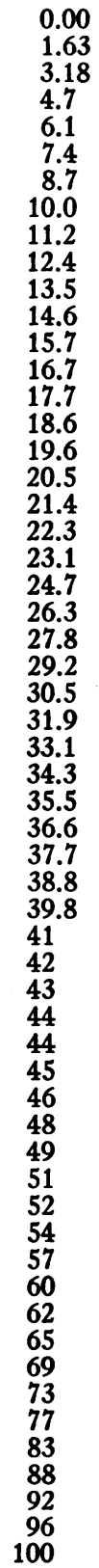 & $\begin{array}{l}0.00 \\
0.96 \\
1.88 \\
2.75 \\
3.59 \\
4.4 \\
5.2 \\
5.9 \\
6.6 \\
7.3 \\
8.0 \\
8.6 \\
9.3 \\
9.9 \\
10.4 \\
11.0 \\
11.6 \\
12.1 \\
12.6 \\
13.2 \\
13.6 \\
14.6 \\
15.5 \\
16.4 \\
17.2 \\
18.0 \\
18.8 \\
19.6 \\
20.3 \\
21.0 \\
21.6 \\
22.3 \\
22.9 \\
23.5 \\
24.1 \\
24.7 \\
25.2 \\
25.8 \\
26.3 \\
26.8 \\
27.3 \\
28.3 \\
29.2 \\
30.1 \\
30.9 \\
31.7 \\
33.6 \\
35.3 \\
36.9 \\
38.3 \\
41 \\
43 \\
45 \\
49 \\
52 \\
55 \\
57 \\
59 \\
\end{array}$ & $\begin{array}{r}0.00 \\
0.56 \\
1.10 \\
1.61 \\
2.10 \\
2.56 \\
3.02 \\
3.45 \\
3.87 \\
4.3 \\
4.7 \\
5.0 \\
5.4 \\
5.8 \\
6.1 \\
6.4 \\
6.8 \\
7.1 \\
7.4 \\
7.7 \\
8.0 \\
8.5 \\
9.1 \\
9.6 \\
10.1 \\
10.5 \\
11.0 \\
11.4 \\
11.8 \\
12.2 \\
12.6 \\
13.0 \\
13.4 \\
13.7 \\
14.1 \\
14.4 \\
14.7 \\
15.0 \\
15.3 \\
15.6 \\
15.9 \\
16.5 \\
17.0 \\
17.5 \\
18.0 \\
18.5 \\
19.6 \\
20.6 \\
21.5 \\
22.4 \\
23.9 \\
25.3 \\
26.5 \\
28.6 \\
30.3 \\
31.9 \\
33.2 \\
34.4\end{array}$ & $\begin{array}{l}0.00 \\
0.33 \\
0.64 \\
0.94 \\
1.23 \\
1.51 \\
1.77 \\
2.03 \\
2.27 \\
2.51 \\
2.74 \\
2.96 \\
3.17 \\
3.38 \\
3.58 \\
3.78 \\
3.97 \\
4.2 \\
4.3 \\
4.5 \\
4.7 \\
5.0 \\
5.3 \\
5.6 \\
5.9 \\
6.2 \\
6.4 \\
6.7 \\
7.0 \\
7.2 \\
7.4 \\
7.6 \\
7.9 \\
8.1 \\
8.3 \\
8.5 \\
8.6 \\
8.8 \\
9.0 \\
9.2 \\
9.4 \\
9.7 \\
10.0 \\
10.3 \\
10.6 \\
10.9 \\
11.5 \\
12.1 \\
12.6 \\
13.1 \\
14.0 \\
14.8 \\
15.6 \\
16.8 \\
17.8 \\
18.7 \\
19.5 \\
20.2\end{array}$ & $\begin{array}{l}0.00 \\
0.09 \\
0.17 \\
0.25 \\
0.32 \\
0.39 \\
0.46 \\
0.53 \\
0.59 \\
0.66 \\
0.72 \\
0.77 \\
0.83 \\
0.89 \\
0.94 \\
0.99 \\
1.04 \\
1.09 \\
1.13 \\
1.18 \\
1.23 \\
1.31 \\
1.39 \\
1.47 \\
1.55 \\
1.62 \\
1.69 \\
1.76 \\
1.82 \\
1.88 \\
1.94 \\
2.00 \\
2.06 \\
2.11 \\
2.16 \\
2.21 \\
2.26 \\
2.31 \\
2.36 \\
2.41 \\
2.45 \\
2.54 \\
2.62 \\
2.70 \\
2.77 \\
2.84 \\
3.01 \\
3.17 \\
3.31 \\
3.44 \\
3.68 \\
3.88 \\
4.1 \\
4.4 \\
4.7 \\
4.9 \\
5.1 \\
5.3\end{array}$ \\
\hline
\end{tabular}

from equations (1), (2), and (3) using the mean $\mathrm{N}_{0} \mathrm{~V}_{\mathrm{n}} / \mathrm{V}$ from Table III ; they are shown in Figures 1 through 6 , which give $k_{1}$ and $k_{2}$ for uptake times of 1,4 , and 24 hours $(t=60,240$ and 1440 minutes).
In using the charts it is assumed that the neck content $\mathrm{N}$ is measured over the ten-minute period from $t-5$ to $t+5$ minutes, and that $E$ is measured with urine produced up to $t$ but collected from the bladder at $t+5$. If the urine is not collected at exactly this time a correction should be applied from Table IV.

\section{NON-ROUTINE TESTS}

In non-routine tests where previous results have been doubtful or where there is reason to suspect that $\mathrm{N}_{0} \mathrm{~V}_{\mathrm{n}} / \mathrm{V}$ may be well away from the expected average value, it is advisable to make initial counts over the neck during the period $\mathbf{t}=\mathbf{0}$ to 10 minutes. This should always be done, if the final count is to be at 30 minutes because the average $\mathrm{N}_{0} \mathrm{~V}_{n} / \mathrm{V}$ may not be precise enough for this short time of uptake.

Having found $\mathrm{N}, \mathrm{E}$, and $\mathrm{N}_{2}$ or $\mathrm{N}_{2,10}$, Table III enables $N_{0} V_{n} / V$ to be calculated, $\phi t$ is found from the figures tabulated earlier (1) so that equation (3) gives $k$, equation (2) gives $k_{1}$ and finally equation (1) gives $k_{2}$.

To save time if $t$ is kept to one of the selected values $\left(\frac{1}{2}, 1,2,4\right.$, or 24 hours), the solution of equation (3) for the value of $k$ may be found from Table V. These methods will become clear from the following examples.

\section{EXAMPLES OF CALCULATIONS}

\section{Routine case at $t=60$ minutes}

Let the observed neck fraction, measured with the long collimator from $\mathrm{t}=55$ to 65 minutes, be $\mathrm{N}=.235$, and the urine fraction collected at $t=73$ minutes be .063 .

From Table IV the corrected excretion fraction must be $\mathrm{E}=.063 \times .91=.057$.

With these values of $\mathrm{N}$ and $\mathrm{E}$, Figures 1 and 2 give

$$
\begin{aligned}
& k_{1}=4.2 \times 10^{-8} \text { minute }^{-1} \\
& k_{2}=1.3 \times 10^{-8} \text { minute }^{-1}
\end{aligned}
$$

\section{Non-routine case at $t=240$ minutes}

Let $\mathrm{N}_{2,10}$, measured over the period $\mathrm{t}=2$ to 10 minutes, have an average value of $.095 ; \mathrm{N}$, observed from $t=235$ to 245 minutes, be .106; and $E$, collected at $t=250 \mathrm{~min}$ utes, be .134.

From Table IV the corrected urine value is

$$
\mathrm{E}=.134 \times .98=.131
$$

From Table III, putting in values

$$
\mathrm{N}_{0} \mathrm{~V}_{\mathrm{n}} / \mathrm{V}=.80 \times .095-.048 \times .106=.071
$$

then

$$
\frac{1-\mathrm{N}_{0} \mathrm{~V}_{\mathrm{n}} / \mathrm{V}}{1-\mathrm{N}-\mathrm{E}}=\frac{1-.071}{1-.106-.131}=1.22
$$


and Table $V$ gives $k=1.34 \times 10^{-8}$ minute ${ }^{-1}$. From equation (2)

so that

$$
k_{1} / k=\frac{.106-.071+.009}{.106-.071+.131}=.265
$$

$$
k_{1}=.265 \times 1.34 \times 10^{-3}=.35 \times 10^{-3} \text { minute }{ }^{-1}
$$

and from equation (1)

$$
\mathrm{k}_{2}=(1.34-.35) \times 10^{-8}=.99 \times 10^{-8} \text { minute }^{-1}
$$

Non-routine case at $t=190$ minutes

Let the measured fractions be $\mathrm{N}_{2,10}=.083, \mathrm{~N}=.317$ and the urine collected at $t=205, E=.188$. Because the time of observation, $t=190$ minutes, is not covered by the charts or Table V, much more calculation is needed in this case.

First $\mathrm{E}$ is corrected from the presumed time of excretion (200 minutes) to the time of observation (190 minutes) by multiplying by the ratio of the corresponding $\phi t$ values taken from the preceding paper (1). Thus the corrected value is

$$
E=.188 \times 124 / 129=.181
$$
III

Then interpolating between the tabulated data of Table

$\mathrm{N}_{0} \mathrm{~V}_{\mathrm{n}} / \mathrm{V}=.86 \mathrm{~N}_{2,10}-.067 \mathrm{~N}=.050$

Equation (2) with these values gives

$$
k_{1} / k=\frac{.317-.050+.009}{.317-.050+.181}=.616
$$

and equation (3) gives

$$
\begin{aligned}
& k=\frac{2.303}{124} \log \frac{1-.050}{1-.317-.181}=5.1 \times 10^{-3} \text { minute }^{-1} \\
& \text { so that } \\
& \text { and } k_{1}=.616 \times 5.1 \times 10^{-3}=3.1 \times 10^{-3} \text { minute }^{-1} \\
& \qquad k_{2}=2.0 \times 10^{-3} \text { minute }{ }^{-1}
\end{aligned}
$$

\section{DISCUSSION}

The method that has been described for calculating the rate constants $k_{1}$ and $k_{2}$ can be applied regardless of the type of measuring equipment used for uptake observations and urine assay; the charts (Figures 1 through 6), however, are only applicable to collimated counting arrangements with a low average factor $\mathrm{N}_{0}\left(\mathrm{~V}_{n} / \mathrm{V}\right)_{2}$ of about .07. When other wide-angle apparatus is employed it is necessary to observe the initial counts over the neck (or less preferably over the thigh) to find the correction for extra-thyroidal neck tissue.

Provided that sufficient counts are obtained for good statistical accuracy, and that the collimator is carefully positioned over the patient's gland, a fair degree of accuracy can be expected with the higher values of $k_{1}$, if measurements are made one hour after injection. For low-k hypothyroid or cardiac cases, however, there will be little or no rise in the counts over the neck in one hour and we suggest that the four-hour read- ings should be selected, and in very low cases an additional set of values should be measured at 24 hours also.

The fixing of diagnostic limits for the rate constants $k_{1}$ and $k_{2}$ depends upon a number of questions distinct from the more physical problems discussed above; in fixing such limits use can be made of some of the information already published by other groups, as will be shown in a later paper describing some of our own clinical results.

In the meantime it can be stated, from the information given in the preceding paper, that the thyroidal rate factor $k_{1}$ minute ${ }^{-1}$ is related to the thyroidal clearance rate $\mathrm{g} \mathrm{ml}$. per minute, for a $70 \mathrm{Kg}$. patient, by the relation

$$
\mathrm{k}_{1}=10^{-8} \mathrm{~g} / 16.3
$$

This means that, if we take $\mathrm{g}=60 \mathrm{ml}$. per minute as the approximate diagnostic borderline between euthyroid and hyperthyroid patients, the corresponding borderline value of $k_{1}$ will be around $3.7 \times 10^{-8}$ minute ${ }^{-1}$. Thus euthyroid values of $k_{1}$ will usually lie below this level, and there will be another not very distinct borderline between hypothyroid and euthyroid groups at about $\mathrm{k}_{1}=2 \times 10^{-4}$ minute $^{-1}$.

\section{SUMMARY}

Based on a preceding paper, routine methods are developed for calculating thyroidal uptake and renal excretion rate factors from measured fractions of the dose of radioiodine observed at an early time $t$ after administration.

Charts are included, for selected times $t$ of 1 , 4 , and 24 hours, giving the rate factors directly from the experimental observations when uptake readings are made with good collimation to keep the extra-thyroidal neck tissue contribution low. Under these conditions such contribution is taken as a mean value for all patients and an uptake study normally requires only one observation over the thyroid gland and one urine assay.

\section{REFERENCES}

1. Oddie, T. H., Meschan, I., and Wortham, J., Thyroid function assay with radioiodine. I. Physical basis of study of early phase of iodine metabolism and iodine uptake. J. Clin. Invest., $1955,34,95$.

2. Werner, S. C., Quimby, E. H., and Schmidt, C., The use of tracer doses of radioactive iodine, $\mathrm{Im}^{\mathrm{m}}$, in the study of normal and disordered thyroid function in man. J. Clin. Endocrinol., 1949, 9, 342. 